\title{
NITRATE ADSORPTION CAPACITY OF ACTIVATED GAMALAMA VOLCANIC ASH
}

\section{Zulkifli Zam Zam ${ }^{\star}$, Nur Asbirayani Limatahu, and Nur Jannah Baturante}

Chemistry Education Department, FKIP, Universitas Khairun Ternate

Jl. Bandara Babullah Kampus Akehuda, Kota Ternate Utara, Indonesia

* correspondence, tel/fax : +6281333233379, email: zulkiflizamzam014@gmail.com

\section{ABSTRACT}

The adsorption process of nitrate from an aqueous solution by using activated Gamalama volcanic ash was investigated. Gamalama volcanic ash (VA) was activated with HNO3 2M. The effect of adsorbent mass and initial nitrate concentration on nitrate adsorption were observed in this study. The adsorption process was conducted using a various mass of adsorbent $(1 \mathrm{~g}, 2 \mathrm{~g}, 4$ $\mathrm{g}, 6 \mathrm{~g}$, and $8 \mathrm{~g}$ ), various initial concentrations of nitrate $(20 \mathrm{mg} / \mathrm{L}, 30 \mathrm{mg} / \mathrm{L}, 40 \mathrm{mg} / \mathrm{L}, 50 \mathrm{mg} / \mathrm{L}$, and $60 \mathrm{mg} / \mathrm{L}$ ). The increasing of adsorbent mass decreased the adsorption capacity was observed. It was also found that the increase in initial concentration increased the adsorption capacity. The highest nitrate adsorption capacity showed by 1 gram adsorbent for $0.167 \mathrm{mg} / \mathrm{g}$, and at nitrate initial concentration $80 \mathrm{mg} / \mathrm{L}$, for $1.831 \mathrm{mg} / \mathrm{g}$. Adsorption isotherm of nitrate on activated VA was determined and figured. These isotherms were modelled according to Freundlich and Langmuir adsorption isotherm.

Keywords: Volcanic ash, adsorption, Langmuir Isotherm, Freundlich Isotherm, adsorbent mass

\section{INTRODUCTION}

Nitrate anions are naturally formed from the nitrogen cycle. This concentration can be increased by increasing nitrate-based industrial waste, animal manure, household waste, and agricultural waste. Nitrate anions are the main nitrogen source needed by plants and animals to synthesize amino acids and proteins. However, it can endanger the environment and health if the concentration exceeds the maximum limit. For the environment, it causes eutrophication of water bodies [1], [2]. For humans, increased nitrate concentrations in drinking water lead to the blue baby syndrome, diabetes, and cancer [3]. Various human activities, such as intensive use of fertilizers, can increase nitrate levels [4].

Methods to overcome the anions nitrate pollution have been developed, such as ion exchange methods, reverse osmosis, chemical methods, biological methods, and adsorption [1], [2]. However, the adsorption method is often used because the cost required is relatively low, does not give side effects such as toxic substances, and can separate cation and anion in wastewater [5]. Many adsorbents can be used to remove 
nitrate from water, such as activated carbon, zeolite, fly ash, or volcanic ash.

Research on nitrate adsorption has been developed using various adsorbents to date. Several studies of nitrate adsorption by different adsorbents had been reported. It was [6] who reported nitrate removal by using carbon activated with an adsorption capacity of nitrate was $0.38 \mathrm{mmol} / \mathrm{g}$. Using zeolite modified to remove nitrate from water, [7] reported that the zeolite modified chitosan has an adsorption capacity of $0.74 \mathrm{mmol} / \mathrm{g}$.

However, carbon adsorbents and natural materials (zeolite and clay) to be applied in the city of Ternate have obstacles because it is highly cost to use activated carbon in Ternate City. For natural material adsorbents (zeolite and clay), information on the existence of these natural materials is still challenging to obtain, so its application will be hard to do. Therefore, we need an adsorbent that is readily available, cost-effective (lowcost adsorbent), and is a natural resource in the city of Ternate. Besides that, several researchers have also reported the effectiveness and efficiency of using volcanic dust as an adsorbent for various pollutants in water. Based on this, it can be said that Gamalama volcanic ash has promising potential to be applied as a novel adsorbent to remove nitrate from water. This research will examine the truth of this potential.

Mount Gamalama is one of the active volcanoes in North Maluku. Gamalama eruptions can produce tons of volcanic ash that is a natural material thrown into the air. Gamalama volcanic ash had been characterized, and FTIR data report that it has many functional groups of the mineral silica and confirmed the presence of albite, cristoballite, and coesite by XRD results [7]. The existence of silica minerals shows that the volcanic ash could be used as an adsorbent for nitrate. Based on this, Gamalama VA was chosen as an adsorbent to remove nitrate from water. The ability of Gamalama volcanic ash as a nitrate adsorbent has not been previously reported. This study will be the rationale for developing various applications of Gamalama volcanic ash as a natural adsorbent to remove pollutants in water.

\section{METHODS}

\section{Materials}

This study uses Gamalama volcanic ash, $\mathrm{HNO}_{3}, \mathrm{NaNO}_{3}, \mathrm{CHCl}_{3}$, water.

\section{Procedure}

\section{a. Adsorbent Preparation}

The volcanic ash collected from the Gamalama eruption was crushed and then sieved using a 45 mesh sieve. $25 \mathrm{~g}$ of natural volcanic dust was mixed with $150 \mathrm{~mL}$ of $2 \mathrm{M}$ HNO3 solution. The mixture was stirred for 3 hours. After that, it was filtered and dried in a heating oven at $150^{\circ} \mathrm{C}$ for 2 hours, then crushed to obtain $\mathrm{HNO}_{3} 2 \mathrm{M}$ activated volcanic ash.

\section{b. Nitrate adsorption}

Each $1 \mathrm{~g}, 2 \mathrm{~g}, 4 \mathrm{~g}, 6$, and $8 \mathrm{~g}$ of acidactivated volcanic ash is put into $50 \mathrm{~mL}$ Erlenmeyer, $25 \mathrm{~mL} 5 \mathrm{ppm}$ nitrate solution is added and homogenized by stirring using a magnetic stirrer at a constant speed for 30 minutes at room temperature. The solution mixture was filtered, and the filtrate was 
analyzed with a UV - Vis spectrophotometer at $200 \mathrm{~nm}$ and $275 \mathrm{~nm}$ wavelengths. To figure out the effect of initial nitrate concentration, the adsorption process was carried out using various nitrate initial concentrations. The nitrate solution was prepared from $1.37 \mathrm{~g}$ of $\mathrm{NaNO}_{3}$ powder dissolved in $1000 \mathrm{~mL}$ water. From this solution it was diluted to produce nitrate solution in various concentrations.

\section{RESULTS AND DISCUSSION}

\section{FTIR Characterization}

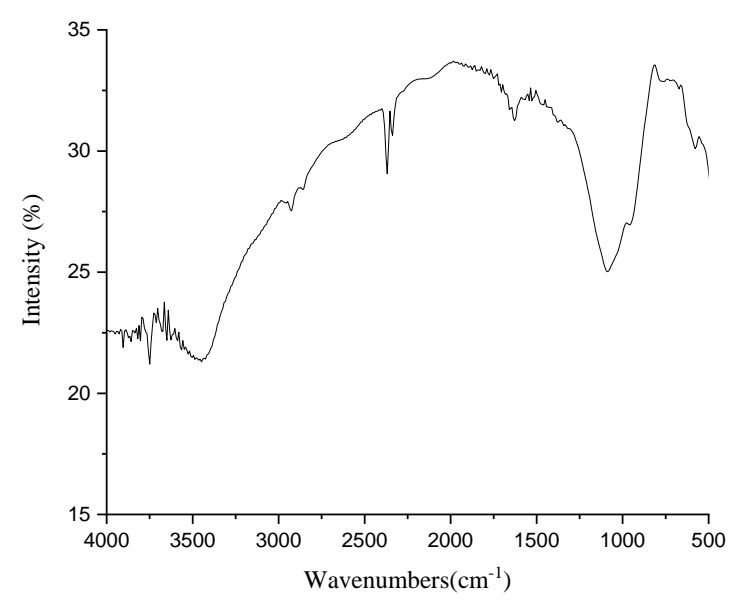

Figure 1. Gamalama Volcanic Ash FTIR Spectra

Infrared characterization results in Figure 1 show that the volcanic ash activated nitric acid having absorption peaks at wave numbers $3670.54 \mathrm{~cm}^{-1} ; 1867.09 \mathrm{~cm}^{-1}$; $1199.72 \mathrm{~cm}^{-1} ; 935.48 \mathrm{~cm}^{-1} ; 800.48 \mathrm{~cm}^{-1}$. The Absorption peak shows $\mathrm{Si}-\mathrm{OH}$ bonds or $\mathrm{Al}-$ $\mathrm{OH}$ stretching vibration at $3670.54 \mathrm{~cm}^{-1}[9]$. Peak $1867.09 \mathrm{~cm}^{-1}$ absorption from $\mathrm{OH}$ of water [10]. Peak $1199.72 \mathrm{~cm}^{-1}$ shows the stretching of Si-O-Si [11]. Asymmetric stretching Si-O-Si showed at $935.48 \mathrm{~cm}^{-1}$, $800.48 \mathrm{~cm}^{-1}$ shows the symmetric vibration of $\mathrm{Si}-\mathrm{O}-\mathrm{Si}$ [12]. Based on the results of FTIR characterization, it can be assumed that in Gamalama volcanic ash, there are minerals composed of silica and alumina frameworks. This statement will then be verified using XRD pattern data, which will identify the types of minerals in the Gamalama volcanic ash.

\section{XRD Characterization}

Based on an XRD analysis conducted by [7], it is known that the type of minerals in Gamalama volcanic ash that is quartz, cristobalite, kaolinite-smectite and albite. Peaks at $2 \theta=22,0145^{\circ}(d=4,03) ; 30,3588^{\circ}$ $(d=2,94) ; 35,7163^{\circ}(d=2,51)$, indicate cristobalite (JCPDS 11-695A). Peaks at $2 \theta=$ $26,5080^{\circ}(d=3,35)$ showed the existence of quartz in VA (JCPDS 5-0490). Peaks at $2 \theta=$ $25,1761^{\circ}(d=3,53) ; 29,1288^{\circ}(d=3,06)$ for coesite (JCPDS 14-654), peak at $2 \theta=$ $24,5651^{\circ}(\mathrm{d}=3,62)$ indicate kaolinitesmectite. The highest intensity peak at $2 \theta=$ $27,9451^{\circ}(d=3,18)$ is indicate the existence of albite (JCPDS IO-393).

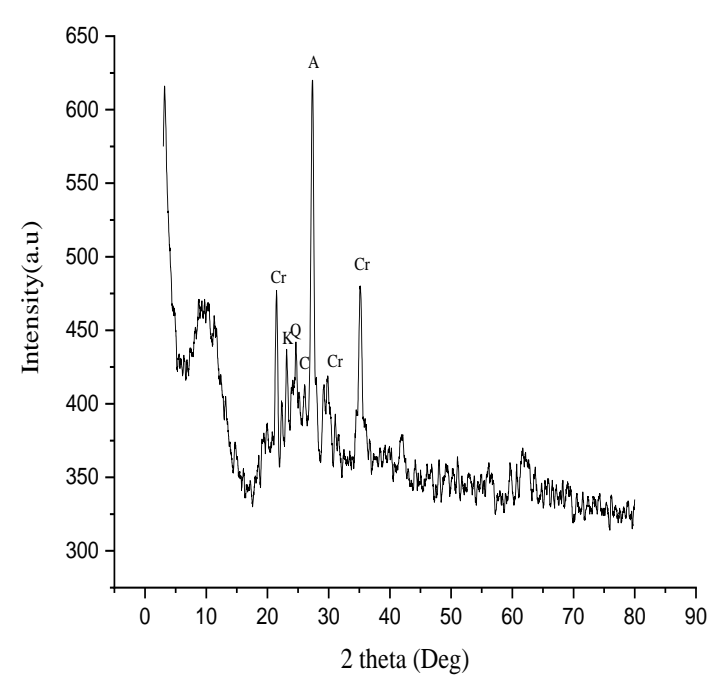

Figure 2. Diffractogram of Gamalama Volcanic ash, A (Albite); $\mathrm{Cr}$ (Cristobalite); Q (Quartz); C (Coesite). 


\section{The effect of adsorbent mass}

Figure 3 shows that the nitrate adsorption capacity increases with decreasing mass of volcanic ash. The use of 1 gram adsorbent indicates the highest adsorption capacity $(0.173 \mathrm{mg} / \mathrm{g})$. The adsorption capacity Continued to decrease as the amount of adsorbent increased until $0.018 \mathrm{mg} / \mathrm{g}$ was reached for 8 grams of adsorbent mass. The aggregation of the adsorbent probably causes this decrease. The same phenomena were reported [13]. The higher adsorbent dosage decreased the adsorption capacity. The higher dosage of adsorbent can cause adsorbent aggregation, which decreased the total surface area and caused the adsorption process to become less effective.

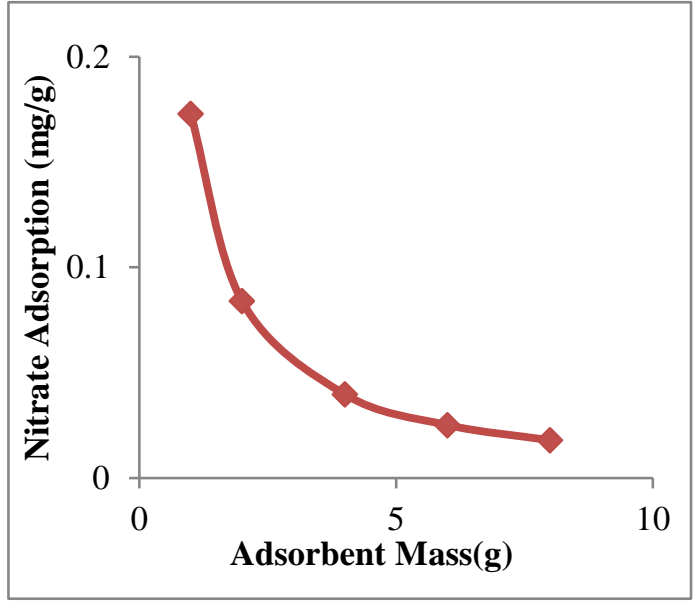

Figure 3. Effect of adsorbent mass on nitrate adsorption

\section{The effect of initial nitrate concentration}

Figure 4 showed that the higher initial concentration of nitrate caused the increase of adsorption capacity. The adsorption capacity continued to increase from 0.872 ; $1.143 ; 1.524 ; 1.67$; and 1.83 , for nitrate initial concentration $41.83 \mathrm{mg} / \mathrm{L} ; 52.81 \mathrm{mg} / \mathrm{L} ; 68.19$
mg/L; 74.17 mg/L; 80.66 mg/L, respectively. The more particles nitrate in solution causes the increase of nitrate adsorption capacity on Gamalama volcanic ash. The adsorption capacity increases with the increasing initial concentration of nitrate [8][14]. The adsorption pattern shows a relatively high affinity between the nitrate ion and adsorbent in lower nitrate concentration, and then it becomes relatively low when interacting with a higher concentration of nitrates [8][15].

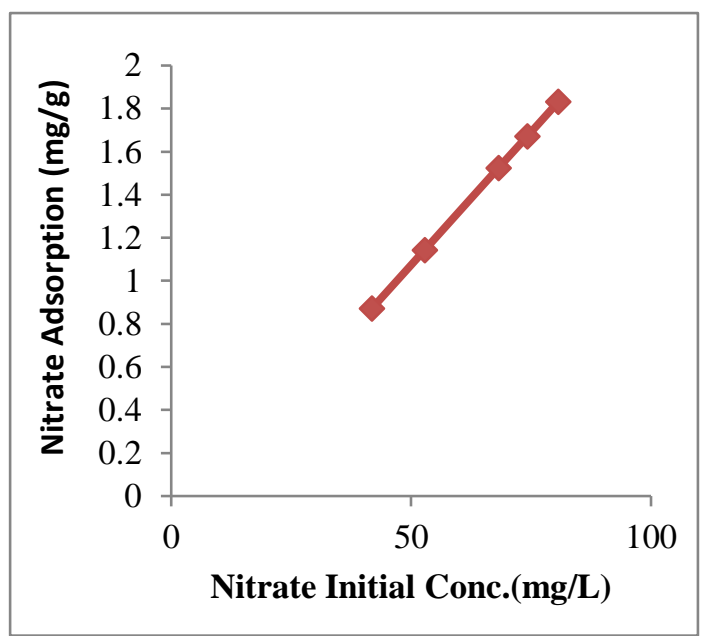

Figure 4. initial concentration of nitrate caused the increase of adsorption capacity

\section{Adsorption Isotherm}

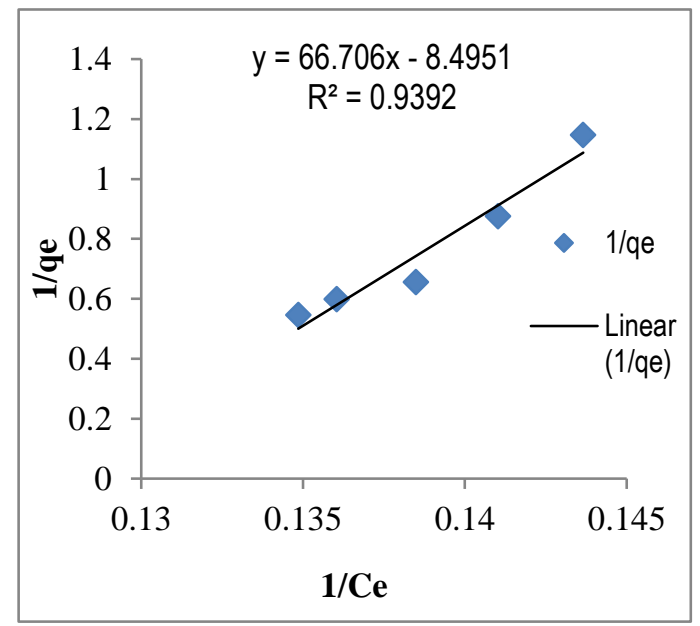

Figure 5. Langmuir Isotherm 


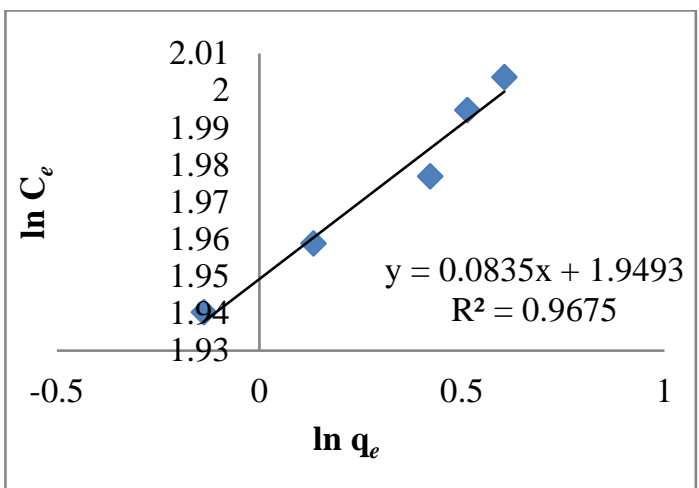

Figure 6. Freundlich Isotherm
This study used Langmuir isotherm (Figure 5) and Freundlich isotherm (Figure 6). to determine the type of adsorption between the adsorbent and the adsorbate. Data obtained from the adsorption isotherm data calculation variation of the initial concentration of nitrate. Parameters are used by both the adsorption isotherm shown in Table 1.

Table 1 Langmuir and Freudlich Isotherm Data

\begin{tabular}{ccccccc}
\hline Isotherm & $\mathbf{q}_{\mathbf{m}}(\mathbf{m g} / \mathbf{g})$ & $\mathbf{b}(\mathbf{L} / \mathbf{m g})$ & $\mathbf{n}(\mathbf{g} / \mathbf{L})$ & $\mathbf{K}_{\mathbf{f}}(\mathbf{m g} / \mathbf{g})$ & $\mathbf{E}(\mathrm{KJ} / \mathbf{m o l})$ & $\mathbf{R}^{2}$ \\
\hline Langmuir & 0.015 & $1.766 \times 10^{-3}$ & - & - & 43.035 & 0.9392 \\
Freundlich & - & - & 11.98 & 7.024 & - & 0.9675 \\
\hline
\end{tabular}

Table 1 shows that the adsorption of nitrate by the volcanic ash following the pattern of the Freundlich and Langmuir isotherm. Langmuir adsorption isotherm occurs on the monolayer adsorption and homogeneous surface. The correlation coefficient $\left(R^{2}\right)$ Freundlich isotherm is closer to 1 than the correlation coefficient of Langmuir isotherm. This suggests that the adsorption occurs in a heterogeneous surface and is caused by physical interaction with an adsorption capacity of $7.024 \mathrm{mg} / \mathrm{g}$. Besides physical interactions, nitrate adsorption on volcanic ash is also possibly caused by chemical interaction from the adsorption energy, which is calculated by Langmuir isotherm obtained at $43.035 \mathrm{~kJ} / \mathrm{mol}$. The chemical adsorption probably due to the electrostatic interaction between silanol/aluminol as the active sites of Gamalama Volcanic Ash and nitrate. The silanol (Si-OH) and aluminol (Al-OH) after acid activation and in an aqueous system could be formed a positive charge [1]. This positive charge can have electrostatic interaction with the negative charge of nitrate. The possibility of electrostatic interaction between Gamalama volcanic ash and nitrate is shown in figure 7, developed from [1].

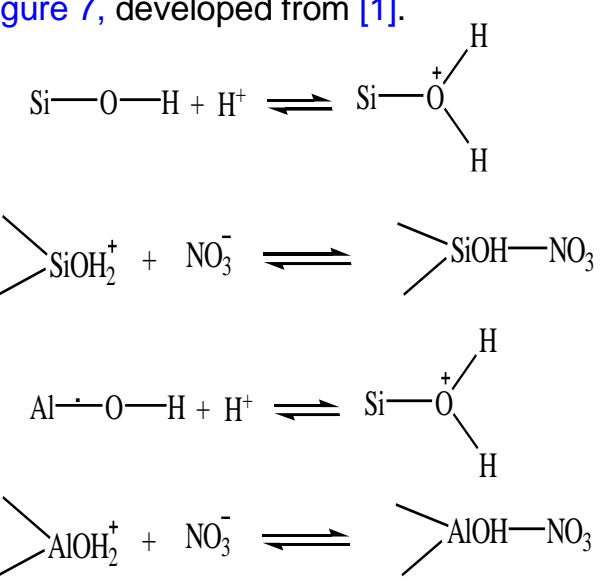

Figure 7. Electrostatic Interaction Between Gamalama Volcanic Ash and Nitrate

\section{CONCLUSION}

Based on the results of this study, it can be concluded that the mass of the adsorbent acid-activated Gamalama Volcanic ash and initial nitrate concentration affect the adsorption capacity of nitrate. The increase of mass adsorbent is decreased the adsorption capacity due to the aggregation effect. Contrarily, the increase of initial nitrate concentration increases the adsorption 
capacity. The isotherm adsorption calculation figured out that the interaction between Gamalama volcanic ash and nitrate is physical and chemical. Based on Freundlich isotherm, the adsorption capacity of Gamalama Volcanic ash on nitrate is $7.024 \mathrm{mg} / \mathrm{g}$.

\section{REFERENCES}

[1] A. Bhatnagar, E. Kumar, and M. Sillanpää, "Nitrate removal from water by nano-alumina: Characterization and sorption studies," Chem. Eng. J., vol. 163, pp. 317-323, 2010.

DOI:10.1016/j.cej.2010.08.008

[2] A. Bhatnagar and M. Sillanpää, "A review of emerging adsorbents for nitrate removal from water," Chem. Eng. J., vol. 168, pp. 493-504, 2011.

DOI:10.1016/j.cej.2010.08.008

[3] I. Mikami, Y. Yoshinaga, and T. Okuhara, "Rapid removal of nitrate in water by hydrogenation to ammonia with Zrmodified porous Ni catalysts," Appl. Catal. B Environ., vol. 49, pp. 173-179, 2004. DOI:10.1016/j.apcatb.2003.12.009

[4] E. V. S. Prakasa Rao and K. Puttanna, "Nitrates, agriculture and environment," Curr. Sci., vol. 79, no. 9, pp. 1163-1168, 2000.

[5] Fahmiati, Nuryono, and Narsito, "Thermodinamics adsorption of Cd ( II ), $\mathrm{Ni}$ ( II ) and Mg ( II ) on 3-Mercapto-1 , 2 , 4-Triazole Immobilized Silica Gel," Indones. J. Chem., vol. 6, no. February, pp. 52-55, 2006.DOI: 10.22146/ijc.21773

[6] A. Afkhami, T. Madrakian, and Z. Karimi, "The effect of acid treatment of carbon cloth on the adsorption of nitrite and nitrate ions," J. Hazard. Mater., vol. 144, no. 1-2, pp. 427-431, May 2007.

DOI: 10.1016/j.jhazmat.2006.10.062

[7] I. Cipta, N. A. Limatahu, S. H. Nur Abu, I. Kartini, and Y. Arryanto, "Characterization of allophane from gamalama volcanic soil, North Maluku, Indonesia," Asian J. Chem., vol. 29, no. 8, pp. 1702-1704, 2017.DOI: 10.14233/ajchem.2017.20620
[8] W. Bekele, G. Faye, and N. Fernandez, "Removal Of Nitrate lon From Aqueous Solution By Modified Ethiopian Bentonite Clay," IJRPC, no. 1, pp. 192-201, 2014. DOI: $10.140 .5 .162 /$ handle/3678

[9] C. Paluszkiewicz, M. Holtzer, and A. Bobrowski, "FTIR analysis of bentonite in moulding sands," J. Mol. Struct., vol. 880, no. 1-3, pp. 109-114, May 2008.

DOI:10.1016/j.molstruc.2008.01.028

[10] B.H Bac, N.T Dung, L.Q Khang, N.V Lam, D.M An, P.V Son, "Distribution and Characteristics of Nanotubular Halloysites in the Thach Khoan Area, Phu Tho, Vietnam," Minerals, vol. 8, no. 7, p. 290, 2018. DOI: 10.3390/min8070290

[11] K. M. S. Khalil, L. A. Elkabee, and B. Murphy, "Formation and characterization of different ceria/silica composite materials via dispersion of ceria gel or soluble ceria precursors in silica sols," J. Colloid Interface Sci., vol. 287, pp. 534-541, 2005. DOI:10.1016/j.jcis.2005.02.041

[12] F. Z. Haque, V. Ali, and M. Husain, "Synthesis and spectroscopic characterization of Nile Blue doped silica gel rods," Optik (Stuttg)., vol. 124, pp. 4287-4291, 2013.

DOI: $10.1016 / j . j$.jleo.2013.01.043

[13] Y. Huang, S. Li, J. Chen, X. Zhang, and $\mathrm{Y}$. Chen, "Adsorption of $\mathrm{Pb}(\mathrm{II})$ on mesoporous activated carbons fabricated from water hyacinth using $\mathrm{H} 3$ PO 4 activation: Adsorption capacity, kinetic and isotherm studies," Appl. Surf. Sci., vol. 293, pp. 160-168, 2014.

DOI: 10.1016/j.jece.2013.07.03

[14] A. Sowmya and S. Meenakshi, "An efficient and regenerable quaternary amine modified chitosan beads for the removal of nitrate and phosphate anions," J. Environ. Chem. Eng., vol. 1, no. 4, pp. 906-915, 2013.

DOI: 10.1016/j.jece.2013.07.031

[15] G. Faye, W. Bekele, and N. Fernandez, "International Journal Of Research In Pharmacy And Chemistry Removal Of Nitrate Ion From Aqueous Solution By Modified Ethiopian Bentonite Clay," IJRPC 2014, vol. 4, no. 1, pp. 192-201, 2014.DOI: $10.140 .5 .162 / /$ handle/3678 